\title{
Research on Tax Policy for Promoting the Transformation and Upgrading of China's Automobile Industry
}

\author{
Xiaoyong Jing \\ Economic School, Jinan University, Guangzhou, China \\ Email: jxy360427@163.com
}

How to cite this paper: Jing, X.Y. (2019) Research on Tax Policy for Promoting the Transformation and Upgrading of China's Automobile Industry. Modern Economy, 10, 484-501.

https://doi.org/10.4236/me.2019.102033

Received: January 28, 2019

Accepted: February 15, 2019

Published: February 18, 2019

Copyright (อ 2019 by author(s) and Scientific Research Publishing Inc. This work is licensed under the Creative Commons Attribution International License (CC BY 4.0).

http://creativecommons.org/licenses/by/4.0/

\section{(c) (i) Open Access}

\begin{abstract}
With the rapid development of the automobile industry, on the one hand, it has promoted the development of the national economy and facilitated people's travel. On the other hand, it has caused environmental pollution, energy shortage, frequent traffic accidents and other hazards. Therefore, in order to create a society in which cars, people and the environment develop harmoniously, it is necessary to promote the transformation and upgrading of the automobile industry. Firstly, this paper analyzes the impact mechanism of tax policy on automobile production, consumption structure and technological innovation of automobile affiliated enterprises. Then, it combs the existing tax policy, and analyzes the effects and defects of policy on the transformation and upgrading of automobile industry. Finally, in view of the shortcomings in the transformation and upgrading of the automobile industry, some suggestions for improving the status quo of taxation policies are proposed.
\end{abstract}

\section{Keywords}

Automobile Industry, Transformation and Upgrading, Tax Policy, New Energy Vehicles, Technological Innovation

\section{Introduction and Literature Review}

Since China promulgated and implemented the "Industrial Policy for the Automotive Industry" in 1994, China's automobile industry has developed vigorously and achieved remarkable results. According to the "China Automotive Industry Yearbook 2018" statistics, since 2009, China has become the world's largest automobile production and marketing market for nine consecutive years. While people enjoy the convenience of cars for their lives, they do not know that envi- 
ronmental pollution, lack of fuel and energy, unreasonable structure of the automobile industry, and insufficient capacity for independent innovation have come one after another, which have severely restricted the sustainable development of the economy and society. In the past, automobile production was dominated by fuel vehicles, and energy demand was huge, which caused two-way pressure on the environment and energy. There is no efficient technology-management-service system in the automotive industry structure. In the international competition, China's auto industry lacks core technology innovation capabilities, and relies too much on technology introduction, resulting in no auto pricing power, and prices are generally too high. Under the multiple predicaments facing the development of the automobile industry, it is imperative to promote the transformation and upgrading of the automobile industry. In 2017, the Ministry of Industry and Information Technology, the National Development and Reform Commission and the Ministry of Science and Technology jointly issued the "Medium and Long-term Development Plan for the Automotive Industry", proposed to improve the construction of the automotive industry innovation system, overcome core technologies, and accelerate the development of automotive products to new energy, energy-saving, intelligent and networked links. , seize the opportunity to achieve catch-up development. Therefore, from the perspective of long-term development, China's auto industry transformation and upgrading direction has two aspects: First, to enhance China's automotive technology innovation capabilities; Second, the transition from the production of traditional fuel vehicles to energy-saving new energy vehicles, complete the diversified structure layout. As a new industry, new energy vehicles, such as vehicle manufacturing, key battery technology, and core components, have not yet completely broken through, and are still at the stage of exploration. Therefore, a large amount of capital investment and various support policies are needed, and tax policy is one of the most important aspects. As the key to regulating the economy, the national taxation policy can increase support for key technologies, accelerate technological transformation, enhance the independent innovation capability of automobile enterprises, guide the automobile consumption market, regulate the development structure of the automobile industry, and promote the transformation of China's automobile industry from the inside out, upgrading to enhance the international competitiveness of independent auto brands.

In recent years, in order to encourage the transformation and upgrading of the automobile industry, a series of supportive policies have been introduced. The academic circles have conducted in-depth discussions on these policies from different angles and have achieved rich results. In terms of the upgrading orientation of the automobile industry, scholars agree that new energy and intelligent driving technology will inevitably lead the future development direction of the automobile. Ma Wei and Liu Yu [1] summarized the development status of China's automobile industry is not strong, need to accelerate transformation and upgrading, propose three models of core technology engine, service-oriented manufacturing, regional integration and development, and promote the coordi- 
nated development of multiple models. Ding Wei and Zhang Tianhua [2] analyzed the fuel gap pressure to limit the sustainable development of fuel vehicles. The development of new energy vehicles is an important strategy to maintain China's energy security, and is also a necessary choice to boost the auto industry and seize the commanding heights of the international auto market. Liu Jianli [3] believes that the introduction of German Industry 4.0 will promote technological changes in the world's automotive industry. Intelligent unmanned driving and new energy vehicles represent the future direction of the development of the automotive industry. In the tax policy of the automobile industry, it is generally interested in the effect of the tax structure and the role of the policy. Liu Jianmin, Xie Rui [4] deeply analyzed the defects of China's auto innovation innovation tax policy (including the risk of independent innovation undertaken by enterprises, the deduction of R\&D expenses is less, the fiscal and taxation system guiding automobile consumption is not perfect), and the corresponding government is proposed. The research and research cooperation promote independent innovation of enterprises, improves the deduction policy of research and development expenses, and implements a taxation policy that encourages energy-saving automobile consumption. Gao Yang, Wang Lijun [5] comparative analysis of the characteristics of consumption tax and vehicle purchase tax, from the design characteristics, the vehicle purchase tax has the nature of consumption tax, there is the problem of overlapping collection. Cheng Xuesong [6] analyzes the correlation between tax policy and the development of automobile industry, and believes that automobile industry capacity innovation, technological innovation, small-displacement vehicles and energy-saving vehicles are powerful points of tax preferential policies, which are conducive to the sustainable development of the automobile industry. Lu Chuncheng and Huang Zhigang [7] made a comprehensive analysis of the tax policy of new energy vehicle consumption. From the three links of purchase, possession and use, the overall tax burden of China's automobile industry was over-represented, and the regulation of taxation on automobile consumption. Limited, does not reflect the direction of the industry.

Reviewing the history of China's automobile industry development, taxation policy has played an indelible role. It has been implemented in an appropriate place, and it has inspired its continuous advancement in the bottleneck period of the development of the automobile industry. It is undeniable that there are some shortcomings in these policies, but through in-depth research and discussion by scholars from all walks of life, they have been increasingly perfected in practice. As the national auto industry strategy becomes clearer, new tax policies will continue to emerge and will be further explored and optimized by scholars.

\section{The Taxation Policy to Promote the Transformation and Upgrading of the Automotive Industry Mechanism Analysis}

1) Analysis of the mechanism of tax policy affecting automobile production 
and consumption structure.

The development of the automobile market is determined by the supply side and the demand side of the automobile. In the tax policy to promote the transformation and upgrading of the automobile industry, the automobile production and consumption structure is mainly regulated by tax incentives such as tax reduction and tax exemption. The following is analyzing the impact of tax policies on automobile production and consumption structure from different perspectives.

a) Analyze the impact of tax policy on automobile production and consumption structure from the perspective of supply and demand curve

Assume that auto companies produce only two types of vehicles: traditional fuel vehicles and new energy vehicles. As shown in Figure 1, the supply curve and demand curve of the traditional fuel vehicle are $S_{\text {traditional }}$ and $D_{\text {traditional }}$, respectively. The initial equilibrium point is $\mathrm{E}_{\text {tradition }}$, the equilibrium price is $\mathrm{P}_{\text {tradi- }}$ tion, and the equilibrium quantity is $\mathrm{Q}_{\text {tradition. }}$. Due to the current immature technology of new energy vehicles and higher production costs than traditional fuel vehicles, the market supply is less than that of traditional fuel vehicles. Therefore, the new energy vehicle supply curve $S_{\text {new energy }}$ is located at the upper left of the traditional fuel vehicle supply curve. In addition, compared with traditional fuel vehicles, new energy vehicles have imperfect supporting facilities, poor safety performance, and fewer automobile manufacturers, resulting in consumers' demand for them is much smaller than that of traditional vehicles. The new energy demand curve $D_{\text {new energy }}$ is located at the lower left of the traditional fuel vehicle demand curve. The initial equilibrium point of new energy vehicles is $E_{\text {new energy, }}$, the equilibrium price is $P_{\text {new energy }}$, and the equilibrium quantity is $Q_{\text {new }}$ energy. From the above: $P_{\text {traditional }}<P_{\text {new energy }}, Q_{\text {tradition }}>Q_{\text {new energy* }}$

As shown in Figure 2, if consumers buy new energy vehicles, the government will give certain tax incentives. With preferential policies, consumers' desire to purchase new energy vehicles will increase, which will reduce the demand for traditional fuel vehicles. Therefore, the demand curve of the new energy vehicle is shifted to $D^{\prime}{ }_{n e w}$ energy right, and the traditional fuel vehicle demand curve is shifted to the $\mathrm{D}_{\text {tradition. }}$. If auto manufacturers produce new energy vehicles, the government also gives certain preferential tax policies. At this time, from the perspective of maximizing the benefits of enterprises, auto manufacturers will increase the production of new energy vehicles and reduce the production of traditional fuel vehicles. The supply curve shifts right to $S_{\text {new energy }}$, and the traditional fuel vehicle supply curve moves left to the $S_{\text {tradition. }}$. Get a new equilibrium point $\mathrm{E}_{\text {new energy }}^{\prime}$ and $\mathrm{E}_{\text {tradition. }}^{\prime}$ Since the $R \& D$ technology of new energy vehicles is still in the development stage, the $\mathrm{R} \& \mathrm{D}$ input cost is higher than that of traditional fuel vehicles, so the price of new energy vehicles with the same configuration performance is still slightly higher than that of traditional fuel vehicles. In recent years, due to consumers' lack of awareness of new energy vehicles, the supply and demand of traditional fuel vehicles is still much higher than that of new energy vehicles. In the future, the supply and demand of new energy 


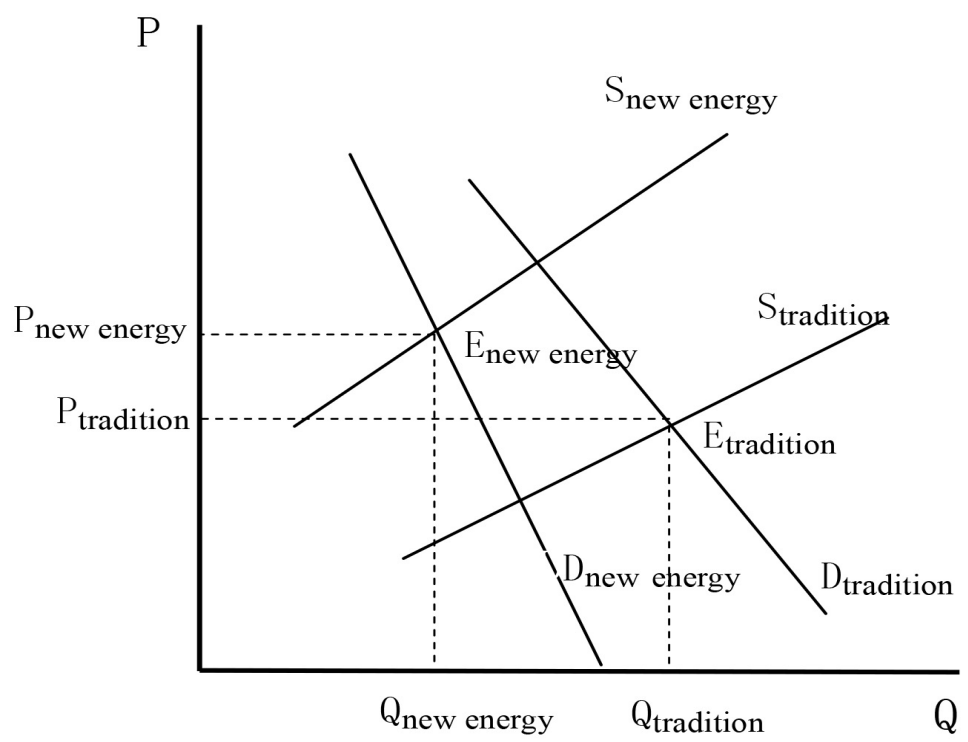

Figure 1. Two kinds of vehicle supply and Demand curves in the initial state.

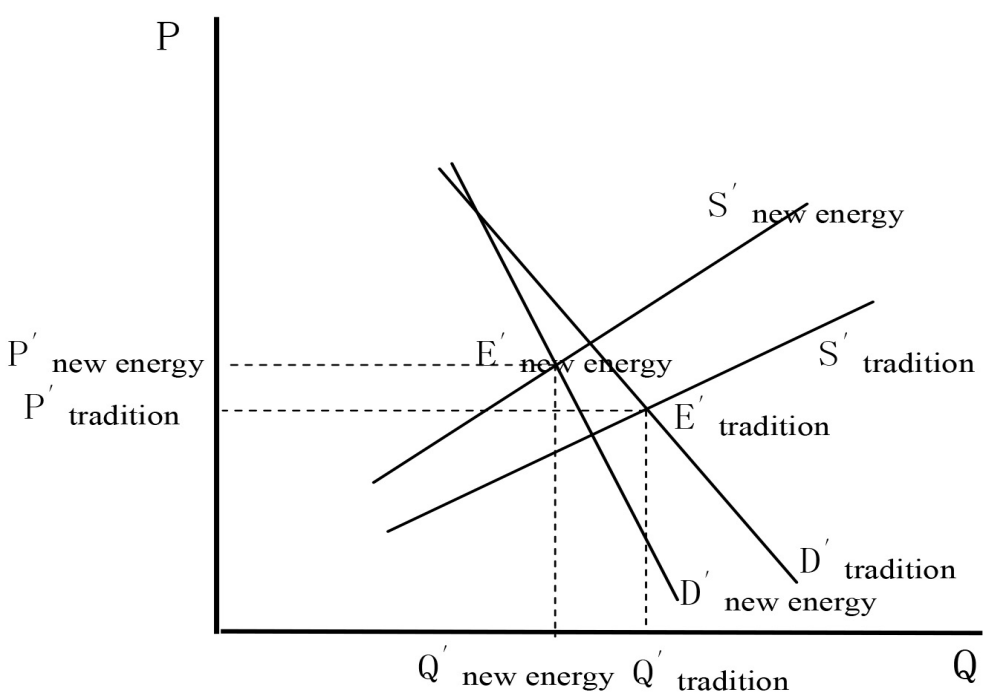

Figure 2. Impact of tax incentives on automobile production and consumption structure.

vehicles and traditional fuel vehicles will be high or low, depending on the market and the government. In summary, after the implementation of tax incentives for auto companies and consumers, $\mathrm{P}_{\text {traditional }}<\mathrm{P}_{\text {new energy }}^{\prime} \mathrm{Q}_{\text {new energy }}<\mathrm{Q}_{\text {tradition. }}^{\prime}$ The actual actual changes are determined according to the preferential policies of the tax policy and the flexibility of the supply and demand curve.

Therefore, the implementation of new energy vehicle tax incentives for auto companies has reduced the production costs of new energy vehicles for auto companies, which will increase the supply of new energy vehicles, reduce the output of traditional fuel vehicles, and expand the supply of new energy vehicles. Implementing preferential tax policies for new energy vehicles for consumers has reduced the purchase cost of new energy vehicles and is conducive to ex- 
panding the demand for new energy vehicles.

b) Analysis of the impact of tax policy on automobile consumption structure from the perspective of indifference curve

As shown in Figure 3, in the initial state, the consumer budget line $\mathrm{AB}$ and the indifference curve $U$ are tangent to the $M$ point, that is, the equilibrium point, the new energy vehicle consumes $X_{\text {new energy, }}$ the traditional fuel vehicle consumption $Y_{\text {tradition, }}$ at this time People get the most utility U. Because of the low production technology, high cost and high price of new energy vehicles, $\mathrm{X}_{\text {new }}$ energy $<\mathrm{Y}_{\text {tradition. }}$. Assuming people's budget revenues remain the same, the government provides tax incentives for new energy vehicle consumption. Although people's surface income has not changed, new energy vehicles are cheaper than traditional fuel vehicles, and the same income can buy more new energy. Automobiles mean that people's actual income increases. From the graph, the budget revenue curve changes from $A B$ to $A B^{\prime}$, and the more effective indifference curve $U^{\prime}$ is tangent to $M^{\prime}$. At this time, the new energy vehicle consumption $X_{\text {new Energy' }}$ traditional fuel vehicle consumption $\mathrm{Y}_{\text {tradition, }}^{\prime}$, and $\mathrm{X}_{\text {new energy }}<\mathrm{X}_{\text {newenergy* }}^{\prime}$

It can be seen that after implementing the preferential tax policy, it will change the consumer's consumption structure, increase the consumption of new energy vehicles, and reduce the consumption of traditional fuel vehicles. For the time being, although a large number of preferential policies have been implemented for new energy source automobile companies, it is not enough to quickly change the consumer's consumption concept, so that the consumer market is still unable to compare with traditional fuel vehicles. This requires the government to promote the concept of automobile consumption. The policy is further improved.

c) Analysis of the impact of tax policy on automobile production structure from the perspective of product conversion curve

It is assumed that auto companies only produce traditional fuel vehicles and new energy vehicles. As shown in Figure 4, two product conversion curves are shown, each representing a combination of a conventional fuel vehicle and a new energy vehicle that can be produced with a given input factor. The product conversion curve $\mathrm{O}_{1}$ is a combination of traditional fuel vehicles and new energy vehicles at a lower level of technology. If the government adopts a production subsidy policy to support car companies, the cost of producing new energy vehicles is lower. In the case of only producing new energy vehicles, more new energy vehicles can be produced, so the product conversion curve becomes $0_{2}$. At this time, $X_{2}>X_{1}$. If the government gives tax incentives to the R\&D investment of auto companies, the technological innovation capability of the enterprise will be enhanced and the overall production efficiency will be improved. Under the same input of production factors, the automakers can produce more two kinds of automobile combinations, and the performance in the figure It is $0_{3}$, at this time $X_{3}>X_{1}, Y_{\text {Tradition }}>Y_{\text {tradition. }}$. The actual changes are also subject to the fiscal and tax incentives. 


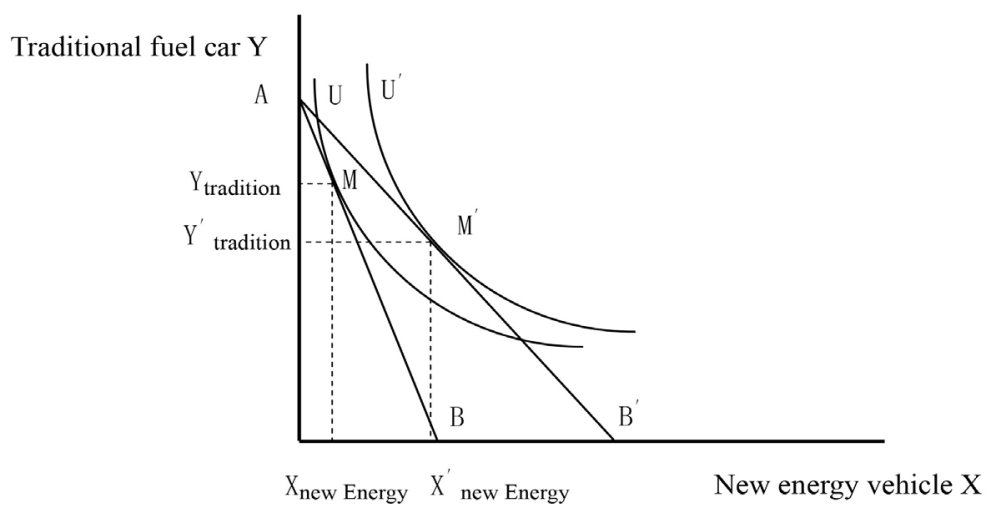

Figure 3. Impact of tax policy on automobile consumption structure.

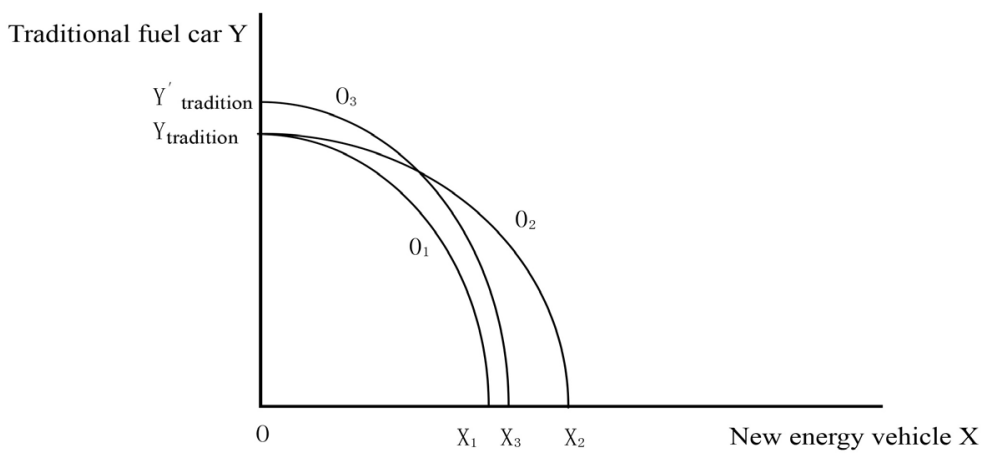

Figure 4. The impact of tax incentives on automobile production structure.

2) Analysis of the mechanism of tax policy affecting automotive enterprises' technological innovation

The transformation and upgrading of the automobile industry is not only the improvement of the structure of automobile products, but also the transformation and upgrading of the core of technological innovation. In order to encourage China's auto-related enterprises to take the road of technological innovation, the government has successively introduced more tax incentives to stimulate technological innovation of enterprises, mainly adopting tax rate concessions, capital depreciation, pre-tax deduction of capital interest, accelerated depreciation of fixed assets, and R\&D expenses. Deducting other preferential methods, reducing corporate tax burden, increasing business profits, and increasing the enthusiasm of corporate $R \& D$ capital investment. $R \& D$ capital investment is the main indicator of enterprise's technological innovation capability. The following are all the R\&D capital investment to measure the ability of enterprise technology innovation.

Neo-classical theory holds that enterprises as an economic entity should pursue profit maximization. Therefore, it is necessary to expand their own business scale through capital investment and obtain economies of scale profits. The enterprise's willingness to invest capital is usually based on the marginal cost of input capital equal to the marginal revenue of input capital. Decide. From the perspective of maximizing the profit after tax, the following is the mechanism 
for the above-mentioned tax incentives to invest in $\mathrm{R} \& \mathrm{D}$ capital of enterprise technology innovation.

Assuming the market is homogeneous, the company has no own cost, and there is no inflation, the production function of the representative enterprise can be expressed by the Cobb-Douglas production function:

$$
Y=K^{\alpha} L^{1-\alpha}
$$

Among them, $Y$ is the enterprise output, $K$ is the enterprise's willingness to invest capital, $L$ is the input labor force (assuming it is fixed), $\alpha$ is the elastic coefficient of capital output $(0<\alpha<1), 1-\alpha$ is the labor output the coefficient of elasticity. Because the company pursues profit maximization, the marginal cost of investing capital should be equal to the marginal return of invested capital.

$$
M P K=\frac{\partial Y}{\partial K}=\alpha(L / K)^{1-\alpha}=\alpha \frac{Y}{K}=C
$$

Based on Joergenson's research on the relationship between tax policy and corporate technology innovation capital investment, a standard capital cost model for corporate capital investment was established. Corporate capital investment needs to consider capital depreciation and capital interest. When considering corporate income tax, the enterprise capital investment profit can be expressed as:

$$
\pi=p Y(1-t)-\omega L-q(r+\lambda) K
$$

Among them, $\pi$ is the enterprise profit, $\mathrm{p}$ is the enterprise output unit price, $t$ is the enterprise income tax $(0<t<1), \omega$ is the labor wage, $q$ is the capital price, $r$ is the borrowed capital interest rate, and $\lambda$ is the capital depreciation rate. Under the purpose of maximizing the profit of capital investment, the first-order partial derivative of $K$ is obtained for $\pi$ and is made zero.

$$
\begin{gathered}
\frac{\partial \pi}{\partial K}=p \frac{\partial Y}{\partial K}(1-t)-q(r+\lambda)=p C(1-t)-q(r+\lambda)=0 \\
C=\frac{q(r+\lambda)}{p(1-t)}
\end{gathered}
$$

It can be known from formula (5) that the cost of capital is directly proportional to the corporate income tax. The higher the corporate income tax rate, the higher the capital investment cost of the enterprise, which will eliminate the enthusiasm of the capital investment of the enterprise.

Let's consider the mechanism of action of a series of tax incentives adopted by the government.

1) Tax rate discount

Suppose the government adopts a preferential tax rate policy for enterprises, that is, the tax rate becomes smaller or even zero, making it $t_{1}$ and $t_{1}<t$. Then, the capital cost becomes $C_{1}=\left(q(r+\lambda) / p\left(1-t_{1}\right)\right)$, and it is easy to know that $C_{1}$ $<C$. After the implementation of the preferential tax rate, the capital cost of the enterprise has become smaller, which has reduced the investment cost of enterprises, encouraged enterprises to increase capital investment, and contributed to 
the increase in the amount of technological innovation.

2) Capital depreciation, capital interest pre-tax deduction

Assuming that the government allows the company's capital depreciation and capital interest to be deducted before tax, the corporate profit expression becomes $\pi=p Y(1-t)-\omega L-q(r+\lambda)(1-z t-y t) K, z$ is The present value of future depreciation of capital, $\mathrm{y}$ is the present value of future interest on capital. Similarly, the capital cost becomes $C_{2}=(q(r+\lambda)(1-z t-y t) / p(1-t))$. If $z+y$ $=1$, the corporate income tax has no effect on the cost of capital. If $z+y>1$, ie $(1-z t-y t)<1-t$, the cost of capital decreases $\left(C_{2}<C\right)$, which will promote the capital of the enterprise. Investment If $z+y<1$, that is, $(1-z t-y t)<1-t$, the capital cost increases and the investor's willingness to invest decreases. Under normal circumstances, $z+y>1$, so capital depreciation and capital interest pre-tax deduction will enhance the company's willingness to invest capital.

3) Accelerated depreciation of fixed assets

If the government allows the firm's fixed assets to accelerate depreciation, the corporate profit expression becomes $\pi=p Y(1-t)-\omega L-q(r+\lambda)(1-z t-y t-x t) K$, and $x$ is the depreciation rate increased for accelerated depreciation. Similarly, the cost of capital becomes $C_{3}=(q(r+\lambda)(1-z t-y t-x t) / p(1-t))$. In the same way as in II, in general, $z+$ $y+x>1$, and thus $1-z t-y t-x t<1-t$, the capital cost is reduced $\left(C_{3}<C\right)$. Therefore, accelerated depreciation of fixed assets will reduce the capital cost of enterprises and increase their willingness to invest.

4) Research and development expenses plus deductions

If the government allows the company's research and development expenses to be deducted, the method of deducting the research and development expenses according to the government's regulations is calculated according to the proportion of research and development expenses, which can be counted as the capital cost of the government for the enterprise. Assuming that the deduction ratio is $\alpha$ $(0<\alpha<1)$, the corporate profit expression becomes $\pi=p Y(1-t)-\omega L-q(r+\lambda)(1-z t-y t)(1-\alpha) K$. Similarly, the capital cost becomes $C_{4}=(q(r+\lambda)(1-z t-y t)(1-\alpha) / p(1-t))$. In general, $z+y>1$ and 0 $<\alpha<1$, it is easy to get $C_{4}<C$. Therefore, the deduction of research and development expenses also reduces the capital cost of enterprises and encourages enterprises to make capital investments.

From the analysis of the above four situations, the government's tax incentives have effectively reduced the capital investment costs of enterprises and increased the enthusiasm of corporate capital investment. This will greatly help to increase the $R \& D$ capital investment of enterprises and achieve rapid development of technological innovation.

\section{Analysis on the Defects of Tax Policy Promoting the Transformation and Upgrading of China's Automobile Industry}

1) Automobile related tax policies in recent years 
With "Automotive Industry Industrial Policy", “Automotive Industry Development Policy", “Automotive Industry Adjustment and Revitalization Plan", "Energy Conservation and New Energy Vehicle Industry Development Plan (2012-2020)" and "Automotive Industry Medium and Long-Term Development Plan" Five strategic policies have been introduced one after another. The Ministry of Finance, the State Administration of Taxation and the local finance and taxation departments have timely introduced a series of tax policies to encourage the healthy, stable and sustainable development of the automobile industry (See Table 1, Table 2).

\section{2) Analysis of effectiveness}

The constantly improving tax policy has continued to stabilize China's automobile power status. According to the "China Automotive Industry Yearbook 2018" statistics, since 2009, China's automobile production and sales ranked first in the world. In 2017, China's automobile production and sales reached 290.514 million and $28,789,900$ respectively, compared with $110 \%$ and $112 \%$ respectively in 2009 (Figure 5). Among them, the market share of new energy vehicles has gradually expanded. The output of new energy vehicles has increased from $0.07 \%$ in 2012 to 2.74 , and the sales volume has increased from $0.07 \%$ in 2012 to 2.69. In 2017, production and sales reached 794,400 and 770,700 respectively (Table 3).

In addition, benefiting from the state's emphasis on the automotive industry R\&D system, the National Development and Reform Commission clearly stated in the "Automotive Industry Adjustment and Revitalization Plan" in 2009 that

Table 1. In recent years, the government introduced important tax policies to regulate automobile production and consumption structure.

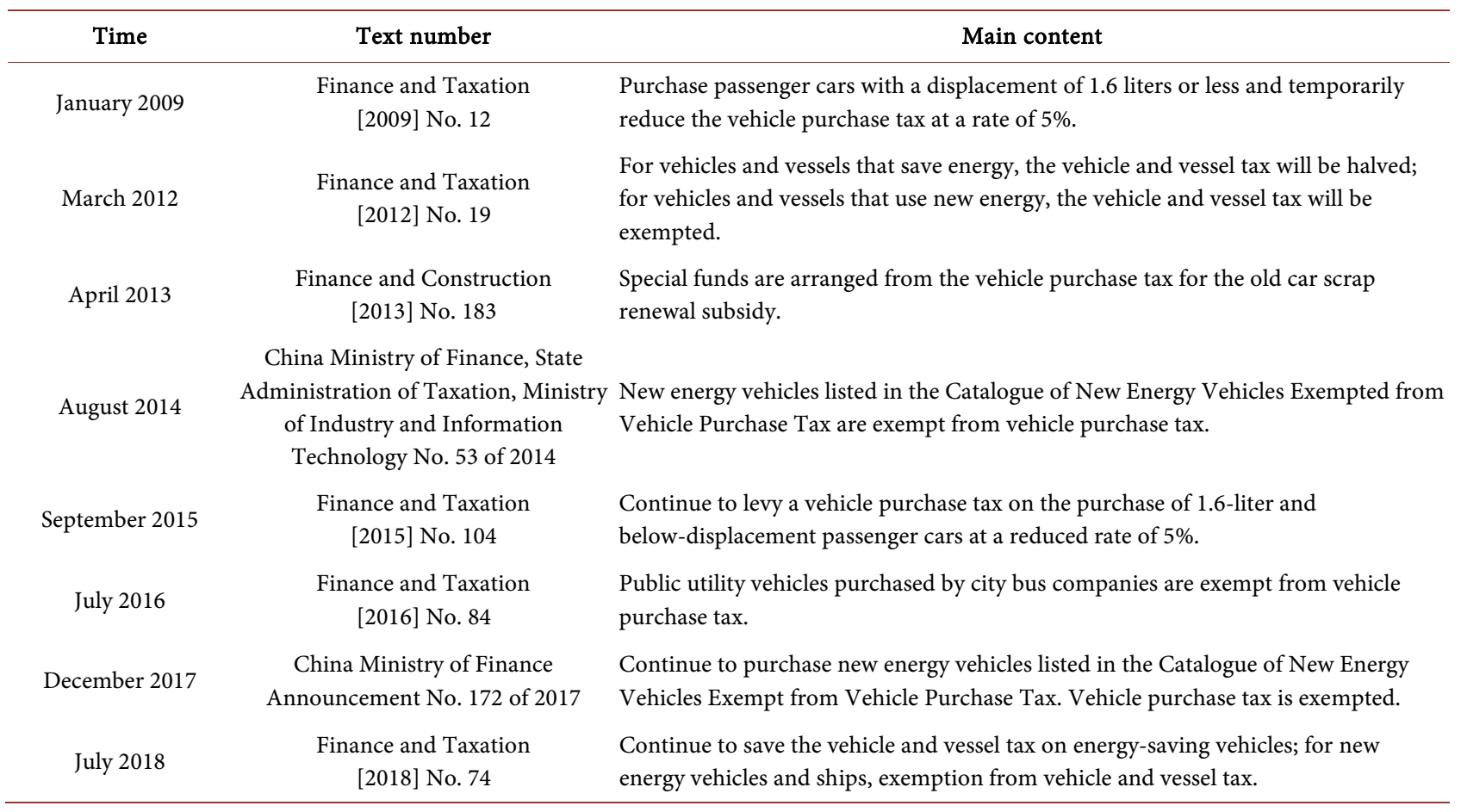


Table 2. In recent years, the government has introduced important tax policies to support technological innovation in automobile companies.

\begin{tabular}{|c|c|c|}
\hline Time & Text number & Main content \\
\hline May 2011 & $\begin{array}{l}\text { Finance and Taxation } \\
\text { [2011] No. } 47\end{array}$ & $\begin{array}{l}\text { Enterprises that meet the high-tech certification standards shall implement a preferential } \\
\text { corporate income tax rate of } 15 \% \text { on their overseas income. When calculating the } \\
\text { overseas credit limit, the total domestic and foreign taxable income shall be calculated } \\
\text { according to the } 15 \% \text { corporate income tax. }\end{array}$ \\
\hline October 2013 & $\begin{array}{l}\text { China Administration of } \\
\text { Taxation Announcement } \\
\text { No. } 62 \text { of } 2013\end{array}$ & $\begin{array}{l}\text { Enterprise technology transfer income can enjoy corporate income tax reduction and } \\
\text { exemption. }\end{array}$ \\
\hline November 2015 & $\begin{array}{l}\text { Finance and Taxation } \\
\text { [2015] No. } 119\end{array}$ & $\begin{array}{l}\text { If the R\&D expenses actually incurred by an enterprise in carrying out research and } \\
\text { development activities are not included in the current profits and losses, the amount of } \\
\text { taxable income will be deducted from the current year's taxable income based on } 50 \% \text { of } \\
\text { the actual amount incurred in the current year. Intangible assets are amortized before tax } \\
\text { at } 150 \% \text { of the cost of intangible assets. }\end{array}$ \\
\hline December 2015 & $\begin{array}{l}\text { China tax Committee } \\
\quad[2015] \text { No. } 23\end{array}$ & $\begin{array}{l}\text { For the self-use equipment (in total investment) included in the new energy vehicle } \\
\text { investment project, the tariff can be exempted. For the research and development of the } \\
\text { electric prototype, the import tariff and the import link value-added tax and consumption } \\
\text { tax can be exempted; the key of the electric vehicle such as the power battery and the } \\
\text { motor controller is Parts can also enjoy a tentative preferential tax rate. }\end{array}$ \\
\hline April 2018 & $\begin{array}{l}\text { China Administration of } \\
\text { Taxation Announcement } \\
\text { No. } 23 \text { of } 2018\end{array}$ & $\begin{array}{l}\text { Automobile-related enterprises newly purchase fixed assets, which can shorten the } \\
\text { depreciation period or adopt accelerated depreciation method; for newly purchased R\&D } \\
\text { instruments and equipment, according to the unit value, how to deduct when calculating } \\
\text { the taxable income. }\end{array}$ \\
\hline
\end{tabular}

Source: Official website of the Ministry of Finance and the State Administration of Taxation.

Table 3. Production and sales of new energy vehicles in China in 2012-2017.

\begin{tabular}{ccccccc}
\hline Year & $\begin{array}{c}\text { Productions } \\
(10,000 \text { vehicles })\end{array}$ & Growth rate (\%) & $\begin{array}{c}\text { Share of total car } \\
\text { production (\%) }\end{array}$ & $\begin{array}{c}\text { Sales } \\
(10,000 \text { vehicles })\end{array}$ & $\begin{array}{c}\text { Growth rate (\%) } \\
\text { Share of total car } \\
\text { sales (\%) }\end{array}$ \\
\hline 2012 & 1.26 & 50.00 & 0.07 & 1.28 & 56.10 & 0.07 \\
2013 & 1.75 & 38.89 & 0.08 & 1.76 & 37.50 & 0.08 \\
2014 & 7.85 & 348.57 & 0.33 & 7.48 & 325.00 & 3.32 \\
2015 & 34.05 & 3033.758 & 1.39 & 53.11 & 53.13 & 1.35 \\
2016 & 51.70 & 51.84 & 1.84 & 50.70 & 53.25 & 2.69 \\
2017 & 79.40 & 53.58 & 2.74 & 77.70 & & 53 \\
\hline
\end{tabular}

Source: China association of automobile manufacturers.

10 billion yuan will be arranged in the newly added central investment as a special fund for technological progress and technological transformation of enterprises. Focus on supporting automobile manufacturers to upgrade their products and improve key technologies such as energy conservation, environmental protection and safety. And a series of tax incentives implemented by the finance and taxation department for the research and development of automobile enterprises, effectively activated the research and development power of China's automobile industry. It can be seen from Table 4 that although the research and development expenditures of China's automobile industry are increasing year by year, 


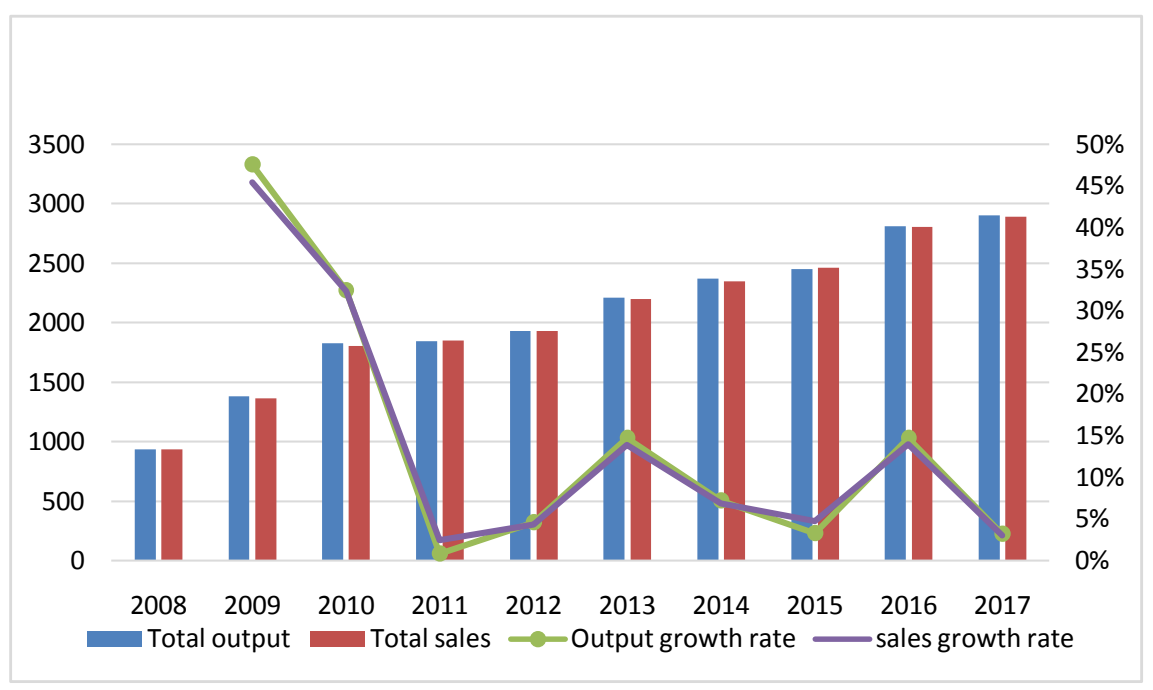

Figure 5. China's automobile production and sales in 2008-2017. Unit: 10,000 vehicles. Source: China association of automobile manufacturers.

Table 4. 2008-2015 Automotive industry research and development expenditure (R\&D), Technical staff composition. Unit: 100 million yuan; million.

\begin{tabular}{cccccccc}
\hline Year & R\&D (A) & $\begin{array}{c}\text { Growth } \\
\text { rate }\end{array}$ & $\begin{array}{c}\text { Operating } \\
\text { income (B) }\end{array}$ & A/B & Staff (C) & $\begin{array}{c}\text { Technical } \\
\text { staff (D) }\end{array}$ & D/C \\
\hline 2008 & 388.7 & - & 18767.0 & $2.07 \%$ & 209.4 & 25.4 & $12.1 \%$ \\
2009 & 460.6 & $18.50 \%$ & 23817.5 & $1.93 \%$ & 216.5 & 26.7 & $12.3 \%$ \\
2010 & 498.8 & $8.29 \%$ & 30762.9 & $1.62 \%$ & 220.3 & 31.1 & $14.1 \%$ \\
2011 & 548.0 & $9.86 \%$ & 33617.3 & $1.63 \%$ & 241.7 & 35.5 & $11.5 \%$ \\
2012 & 591.3 & $7.90 \%$ & 36373.1 & $1.63 \%$ & 250.8 & 37.3 & $12.0 \%$ \\
2013 & 727.8 & $23.08 \%$ & 37155.3 & $1.96 \%$ & 340.0 & 42.4 & $13.2 \%$ \\
2014 & 794.4 & $9.15 \%$ & 39942.0 & $1.99 \%$ & 350.5 & 47.6 & $13.6 \%$ \\
2015 & 928.0 & $16.82 \%$ & 44617.5 & $2.08 \%$ & 360.0 & 49.3 & $13.7 \%$ \\
\hline
\end{tabular}

Source: China association of automobile manufacturers.

the growth rate is unstable, and most of the years account for less than $2 \%$ of revenue, which cannot meet the needs of automobile enterprises for technological innovation and development.

3) Analysis of defects

Although the transformation and upgrading of China's automobile industry has achieved certain results after the introduction of various support policies, there are still many areas to be improved. Based on the implementation expectations and market performance of various tax policies, the following shortcomings are summarized:

a) Unreasonable tax structure

Taxes affecting the three stages of production, purchase and use of automobiles mainly include value-added tax, corporate income tax, customs duties, consumption tax, vehicle purchase tax, vehicle and vessel tax, fuel tax, etc. Gov- 
ernment taxation is mainly concentrated on production and purchase. For example, auto companies need to pay VAT and corporate income tax, and if they import and produce parts, they need to pay customs duties and import value-added tax. Consumers are required to pay VAT, consumption tax, vehicle purchase tax (new energy vehicle reduction) at the purchase stage. In the use of the link, the owner pays a vehicle and vessel tax of several hundred to several thousand per year according to the displacement of the vehicle and a fuel tax of about 1.5 yuan per liter at the time of use. After calculation, the automobile production and purchase links accounted for $66 \%$ of the total tax burden, and the use of the link accounted for $34 \%$. On the one hand, such a tax structure will undoubtedly affect consumers' desire to buy cars, thus curbing the expansion of the automobile consumer market. In the past two years, China's automobile consumption growth has slowed down, and this has a certain influence. On the other hand, when theuse tax burden is too low, people's awareness of environmental protection and energy conservation will gradually fade, and they will not be able to effectively guide consumers to purchase small-displacement energy-saving and new-energy vehicles.

b) Tax incentives to support technological innovation in auto companies need to be improved

First of all, the current technological innovation tax incentives cannot fully play their inclusive role. Although the implementation of the preferential tax policy has promoted the investment of research and development capital, intangible assets and fixed assets of automobile enterprises to a certain extent, it is mainly aimed at qualified enterprises or projects, such as high-tech enterprises, joint venture car enterprises, new energy vehicle investment, etc. Obtaining qualification certification requires a complicated application process, which will greatly incur manpower, material resources and financial resources. At the same time, it will lead to the phenomenon of "policy misunderstanding". Enterprises and projects that do not need policy support fail to receive funding, and enterprises and projects that need to be funded have excess preferential policies. Secondly, from the perspective of tax incentives, direct preferential measures such as tax rate concessions, tax reductions, and tax rebates are the main methods, of which income tax and value-added tax account for a relatively large proportion. In the indirect preferential means represented by the deduction of research and development expenses, the scope of deduction is too narrow, and the deduction ratio is determined only based on whether or not intangible assets are formed. For auto companies, the project has a large investment in the early stage, high risk and long return on investment. The R\&D expenses should be expanded and deducted, and the value-added tax generated for the introduction of advanced equipment for technological innovation can be increased.

c) The guiding role of tax policies for new energy vehicles is limited

In the field of new energy vehicles, the various taxes and fees that car companies need to pay for the production of new energy vehicles, the construction of new plants, the purchase of raw materials, the introduction of new technologies, 
etc., are higher than the production costs of traditional fuel vehicles, so the price of new energy vehicles is higher. Although the state has adopted measures such as car-free tax and vehicle purchase tax to encourage the consumption of new energy vehicles, it has reduced the cost of purchasing new energy vehicles to a certain extent. However, consumers buy cars, self-interestedness is deeply rooted in the heart, and environmental awareness is relatively lacking. It is difficult to attract consumers to sacrifice personal interests in exchange for the positive benefits of society simply by eliminating the meager tax. At the same time, based on the imperfect supporting facilities, it will cost more than the repair cost of traditional fuel vehicles in the later maintenance phase. In general, the cost of using new energy vehicles is higher than consumer expectations, and the existing tax policy cannot fully change the concept of consumers buying cars in a short period of time. Judging from the behavior of car companies, with the entry and exit of preferential policies becoming lower and lower, and the support policies being closely introduced, the phenomenon of "cheat" has emerged. Such as the emergence of subsidies overlap or excessive subsidies, resulting in some car companies to chase tax subsidies, relax car quality supervision, the government's purchase of new energy vehicles idle and other issues, leading to policy failure.

\section{Tax Policy Suggestions for Further Promoting the Transformation and Upgrading of China's Automobile Industry}

In order to adapt to the new normal of the economy and meet the needs of supply-side structural reforms, China's auto industry can only keep up with the pace of the international market through transformation and upgrading, in order to realize the dream of a car-powered country. The transformation and upgrading of the automobile industry is inseparable from the support of taxation policies. The guiding and regulating role of taxation policies is conducive to further optimizing the layout of the automobile industry, enhancing its core competitiveness and achieving a comprehensive upgrade of the automobile industry.

1) Improve the tax structure of the automobile industry

First of all, give the car tax a weight loss. So far, there is no preferential policy for enterprise income tax and value-added tax for car companies. It can be used to increase the rate of corporate income tax and value-added tax for car companies in energy-saving and environmentally-friendly vehicles or technology research and development. The enthusiasm can also promote car companies to increase R\&D capital investment for technological innovation.

Second, reduce the burden on consumers to buy a car. Focus on adjusting vehicle purchase tax and consumption tax. Since there are many characteristics in the academic circles that the vehicle purchase tax has a consumption tax and there is a suspicion of overlapping taxes, the vehicle purchase tax can be abolished and incorporated into the consumption tax. China's automobile consumption tax adopts a seven-grade tax rate, which is only classified by the cylinder capacity and cannot reflect the degree of consumer energy consumption 
and exhaust emissions. The tax rate can be reasonably divided based on the mileage of the road, the difference in power energy (gasoline, diesel, electric energy), fuel consumption, and carbon dioxide emissions.

Finally, increase the tax burden of the use period. Guiding low-carbon travel requires further improvement in fuel taxes and vehicle and vessel taxes. For the fuel tax, first, the fuel tax can be changed from the in-price tax to the extra-price tax to increase the tax sensitivity of the owner; the second is to implement the step fuel tax on a monthly basis, which can reduce the monthly usage rate of consumers and reduce fuel consumption. Saving energy and promoting the consumption of energy-efficient cars. For the vehicle and vessel tax, considering the fairness of the tax system and the policy orientation of energy conservation and emission reduction, it is recommended to use the value of the automobile or the power of the engine as the basis for tax calculation, and adopt the combination of the ad valorem and the quantity to implement the compound collection method. It is good to highlight the vehicle and vessel tax as an attribute of property tax.

2) Preferential policies to promote the technological innovation of automobile enterprises

On the one hand, relevant departments should continue to implement tax incentives that support enterprise technological innovation, and establish a sound tax incentive system in terms of independent innovation, new equipment or technology purchase and personnel training or introduction. For independent innovation, the government should increase support for R\&D investment of upstream and downstream enterprises in the automobile industry chain. For enterprises that use technological achievements in the production process, they can give preferential policies for income tax. If the conversion fails, they can the conversion of technical achievements, a certain percentage of the taxable income deduction. For the introduced intellectual property rights such as manufacturing technology, patent licenses, and technology licenses, a certain percentage of tax refunds may be applied according to the contract transaction amount. In terms of talent development, the government should give certain talents to introduce subsidies, provide housing subsidies or low-rent housing, and encourage enterprises to strengthen the training of talent theory and practice.

On the other hand, government departments can focus on new energy vehicles and intelligent networked automobile companies, and implement a certain proportion of research and development expenses, fixed assets, capital accelerated depreciation and capital interest pre-tax deduction for related enterprises to encourage them to increase investment in innovation and R\&D; New energy vehicle core technology research and development special fund, dedicated to the research and development of new energy vehicles and intelligent network related technologies; strongly support the promotion of "production, study and research" cooperation projects, the establishment of automobile manufacturing enterprises, parts manufacturing enterprises, scientific research institutions. And the automobile technology research and development platform jointly estab- 
lished by universities, guided by market development, taking enterprises as the main body, promoting the complementary advantages of school-enterprise cooperation, and concentrating financial and material resources to promote the speed and quality of research and development of core technologies such as new engines, key components, hybrid technologies, energy-saving and environmentally friendly battery technologies, and realize the transformation and application of scientific and technological achievements.

3) Tax policy to encourage the development of new energy vehicles

a) Clearly define industry standards and technology development routes. As the key development direction of the automobile industry in the future, new energy vehicles should clearly divide the industry standards and technological development routes, and the tax support policies can correctly guide, support and regulate the transformation and upgrading of the automobile industry. Focusing on the development plan of the automobile industry, the corresponding tax policy framework is formulated, combined with the development stage of the automobile industry, and the corresponding policy tools are used reasonably to ensure the validity and continuity of the tax policy applied in the whole process of the development of the automobile industry. At the same time, we strictly control the entry barriers, increase market supervision, and curb the phenomenon of "cheat compensation".

b) Broaden the scope of tax incentives for new energy vehicles. At the supply end, China's preferential policies for car companies are more based on the technical standards, to give the set corporate income tax preferential tax rate, obviously, this incentive for technological innovation is insufficient. On the demand side, the existing tax incentives are mainly for the vehicle purchase tax and the vehicle and boat tax reduction and exemption policies. The incentives are not great, so the incentive effect on automobile consumption is not good. In the United States, the purchase of new energy vehicles can obtain a certain amount of federal income tax relief, which greatly enhances the enthusiasm of citizens to buy new energy vehicles. Therefore, the "double tax reduction" policy can be considered to encourage both production and consumption. Expand the scope of preferential tax categories, including not limited to setting VAT reduction, accelerated depreciation, and personal income tax deduction.

c) Improve the basic infrastructure of new energy vehicles. Whether new energy vehicles can be promoted and used, the role of infrastructure facilities is undoubted, the government should vigorously support the construction of basic supporting industries. For enterprises engaged in new energy vehicle batteries, electric drive construction, charging stations, charging equipment and other supporting industries, the government can grant certain corporate income tax reductions or financial subsidies or low-interest interest-free loans in the production chain, such as the above-mentioned enterprises. In the case of a loss, the enterprise may be allowed to use the income of the subsequent year to fill; for the enterprise engaged in private equity investment, the investment income of the investment in the new energy automobile infrastructure industry may be 
fully taxed when the enterprise income tax is paid Deductions; enterprises and individuals who build self-built charging piles can be given a certain value-added tax refund.

\section{Research Conclusion}

Through the above analysis, we can see that in the process of transformation and upgrading of the automobile industry, the tax policy has played the role of "catalyst", which stimulates the technological innovation of automobile enterprises, regulates the production of automobile enterprises and purchases structures from consumers, and inspired the development of energy-efficient new energy vehicles. However, the existing tax policy also has certain limitations. The irrational structure of the tax system leads to insufficient purchasing power of energy-saving vehicles. The tax incentives with insufficient strength cannot support the technological innovation of car enterprises. Only in accordance with the characteristics of the development of the automobile industry and the various constraints encountered, timely revision of the tax policy system of the automobile industry can be more conducive to the growth of China's automobile industry from large to strong. After combing the tax policy related to the automobile industry, this paper proposes a series of policy recommendations that help the automobile industry to transform and upgrade according to the impact mechanism of the tax policy on the automobile industry, such as merging vehicle purchase tax, adjusting vehicle and vessel tax, and reducing personal income tax to promote new Energy vehicle consumption, increase tax incentives for car companies to promote technological innovation. However, I don't know much about the auto industry. I can only propose some amendments to the tax structure from the perspective of consumers. I cannot propose a complete tax policy system based on industrial policies and tax policies, which needs to be improved through future study and research.

\section{Conflicts of Interest}

The author declares no conflicts of interest regarding the publication of this paper.

\section{References}

[1] Ma, W. and Liu, Y. (2014) Multi-Model Research on the Upgrading of China's Automobile Industry. Jiangxi Social Sciences, 5, 53-58.

[2] Ding, Y. and Zhang, T. (2014) Research on the Effect of Fiscal and Taxation Policies to Promote the Development of New Energy Automobile Industry. Tax Research, 9 , 16-20.

[3] Liu, J. (2015) Industry 4.0 and China's Automobile Industry Transformation and Upgrading. Economic System Reform, 6, 95-101.

[4] Liu, J. and Xie, R. (2008) Research on Fiscal and Taxation Policies to Promote Independent Innovation in Automobile Manufacturing Industry. Financial Research, $1,22-24$ 
[5] Cheng, X. (2009) Using Tax Policy to Promote the Development of China's Automobile Industry. Tax Research, 9, 45-48.

[6] Gao, Y. and Wang, L. (2011) Problems in China's Automobile Consumption Tax Policy and Suggestions for Improvement. Tax Research, 11, 57-58.

[7] Lu, C. and Huang, Z. (2011) Analysis on Tax Policy of New Energy Vehicle Consumption. Tax Research, 5, 29-32. 